\title{
SNAKE VENOM DERIVED FIBRIN ADHESIVE IN DOG UTERINE HEALING. BIOMECHANICAL STUDY
}

MORAES J. R. E. (1), CAMPLESI A. C. (1), CORREIA P. H. A. (1), SHIMANO A. C. (2), FERRARO G. C. (1), MORAES F. R. (1)

(1) Department of Veterinary Pathology (DPVE), School of Agrarian and Veterinary Sciences (FCAV), São Paulo State University (UNESP), Jaboticabal, São Paulo, Brazil; (2) Laboratory of Bioenginnering, Ribeirão Preto School of Medicine (FMRP), São Paulo University (USP), Ribeirão Preto, São Paulo, Brazil.

ABSTRACT: Healing is a complex process with many interfering factors. The objective of this work was to evaluate regeneration strength of non-pregnant adult dog uterus when snake venom derived fibrin adhesive is used to reinforce hysterorrhaphy. Maximum limit and rigidity were analyzed. Twenty uterine horns from 10 dogs were hysterotomized and distributed into 2 equal groups. Hysterorrhaphy was performed using the Shimieden-Cushing double layer suture. In one group, animals received snake venom derived fibrin adhesive as reinforcement. Although neither variable was significantly different, our results showed higher rigidity values in the adhesive group. This can be attributed to the adhesive's effect on organ elasticity or to more granulation tissue formed in the uterine scar.

KEY WORDS: biomechanical properties, healing, dog uterus, fibrin adhesive, snake venom.

\section{CORRESPONDENCE TO:}

J. R. E. MORAES, Departamento de Patologia Veterinária - FCAV/Unesp, Via de Acesso Prof. Paulo Donato Castellani, Km 5, 14884-900, Jaboticabal, SP, Brasil. Phone: 550113209 2662. Email: irmoraes@fcav.unesp.br. 


\section{INTRODUCTION}

The reliable way to determine the mechanical properties of biological materials is by standard mechanical tests, which provide comparable and reproducible results (24). The strength in the adhesion and healing of sutures can be evaluated with mechanical traction tests. In these, material is submitted to two opposing forces, applied at different points and in opposite directions causing longitudinal stretching and transverse reduction. This provides a curve (load $x$ deformation), which for small forces, is a straight line (elastic phase), corresponding to deformation proportional to force, followed by a curve (plastic phase), in which there is no proportionality between deformation and force (3).

Maximum limit is the maximum tension that the material can bear prior to rupturing. It can be determined from maximum deformation and load recorded in each test; rigidity is material specific and equal to the modulus of elasticity, which is the ratio between tension and deformation during the material's elastic phase (24).

The more mechanical characteristics grouped in traction tests of a specific biological material, the more conclusive the test, as it is believed to be closer to real functional conditions (16). This way, several conditions have been tested in different tissues such as muscle, ligaments, tendons, etc.

In this work we studied the maximum limit and rigidity of mechanical traction in dog uterus hysterorrhaphy with and without snake venom derived fibrin adhesive used as a reinforcing agent.

\section{MATERIALS AND METHODS}

Ten non-pregnant adult crossbred female dogs were used. They were kept in kennels, receiving a balanced diet of food and water ad libitum. The animals were randomly assigned into two experimental groups of 10 uterine horns each: (G1) hysterotomy and hysterorrhaphy; (G2) hysterotomy, hysterorraphy and fibrin adhesive.

After 12-hour fasting, the animals were anesthetized using chlorpromazine $(1 \mathrm{mg} / \mathrm{Kg})$ with tiletamine and zolazepam $(10 \mathrm{mg} / \mathrm{Kg})$. Animals underwent laparotomy after a midline abdominal incision in sterile conditions, and bilateral hysterotomy (longitudinal incision of $3 \mathrm{~cm}$ ) followed by hysterorrhaphy with Shimieden-Cushing double-layer suture (29) and 3-0 Vycril $^{\circledR}\left(\right.$ Ethicon $^{\circledR}$, Johnson \& Johnson - SP) on an atraumatic needle. The fibrin adhesive was applied to the suture in G2. The fibrin 
adhesive consists of equal amounts of cryoprecipitate and venom fraction, previously diluted in calcium chloride, and mixed together at time of application (27). Conventional laparorrhaphy, subcutaneous and skin suture were performed on all the animals.

Post-operative care consisted of daily change of dressing and antibiotics for 7 days (penicillin benzathine $40,000 \mathrm{Ul} / \mathrm{Kg}$ ). On the $15^{\text {th }}$ post-operative day, the animals underwent another laparotomy with ovariohysterectomy, the suture dehiscence, adherence, organ constriction, and color were macroscopically evaluated. Approximately $8-\mathrm{cm}$ segments of the uterine horns were separated, washed, immersed in $0.9 \%$ saline solution, and frozen until day of traction tests.

Biomechanical tests were performed in a Universal Test Machine (UTM) to evaluate organ rupture site suture line for maximum limit (maximum load and deformation) and rigidity. Both ends of the uterine horn samples were fastened in jaws set at a standard $4 \mathrm{~cm}$ apart. Jaws were aligned so that load was applied longitudinally. For the reading of loads, we utilized a load cell $\left(\operatorname{Kratos}^{\circledR}\right)$, with capacity of $50 \mathrm{Kgf}$, associated to an extensometry bridge (Sodomex ${ }^{\circledR}$ ) that was coupled to the UTM. A dial micrometer (Mitutoyo ${ }^{\circledR} ; 0.01 \mathrm{~mm}$ precision) was used to measure deformations at $0.2 \mathrm{~mm}$ intervals until rupture of the uterine horn. A preload of $120 \mathrm{~g}$ was applied to all tests, with accommodation time of 60 seconds, in order to eliminate the gross slack between the machine, accessory and sample. During the tests, physiologic solution was dripped on to the samples to prevent dehydrate avoiding possible modification of results.

Statistical analysis was by Student $t$ test with significance considered at $5 \%$.

\section{RESULTS}

Macroscopic examination of the uterine horns showed light omental adherences on the suture line; these were more evident in $\mathrm{G} 1$ animals. There was also slight fibre thickening due to the healing process.

The load $x$ deformation curves from the biomechanical study are shown in Figure 1. In G1, 2 (25\%) fragments ruptured close to the clamp, 2 (25\%) at one end of the suture, $1(12.5 \%)$ on the suture line, and $3(37.5 \%)$ distal to the suture line. In G2, 1 $(11.1 \%)$ fragment ruptured close to the clamp, $3(33.3 \%)$ at one end of the suture, 1 $(11.1 \%)$ on the suture line, and $4(44.4 \%)$ distal to the suture line (Table 1; Figure 2 ). 
At the maximum limit, the mean and standard deviations for uterine horn maximum load in $\mathrm{G} 1$ was $11.60 \pm 4.07 \mathrm{~N}$, and in $\mathrm{G} 2$ was $11.96 \pm 2.81 \mathrm{~N}$. There was no significant difference between groups $(P>0.05 ; t=0.8454)$, which indicates that fibrin adhesive did not influence the maximum load supported by uterine horns (Figure 3). Mean maximum uterine horn deformation in $\mathrm{G} 1$ was $11.50 \pm 3.27 \times 10^{-3} \mathrm{~m}$ and in $\mathrm{G} 2$, $9.93 \pm 4.61 \times 10^{-3} \mathrm{~m}$. There was no significant difference between groups $(P>0.05$; $\mathrm{t}=0.4434$ ), which indicates no difference in stretching resistance between groups (Figure 3).

Mean rigidity for uterine horns in $\mathrm{G} 1$ was $941.74 \mathrm{~N} / \mathrm{m}$ and in $\mathrm{G} 2,1252.93 \mathrm{~N} / \mathrm{m}$. There was no significant difference between groups $(P>0.05 ; t=0.1221)$. However in absolute numbers, G2 values were higher, which can be attributed to the loss of elasticity, probably due to more granulation tissue formed because of the fibrin in the adhesive (Figure 3). 

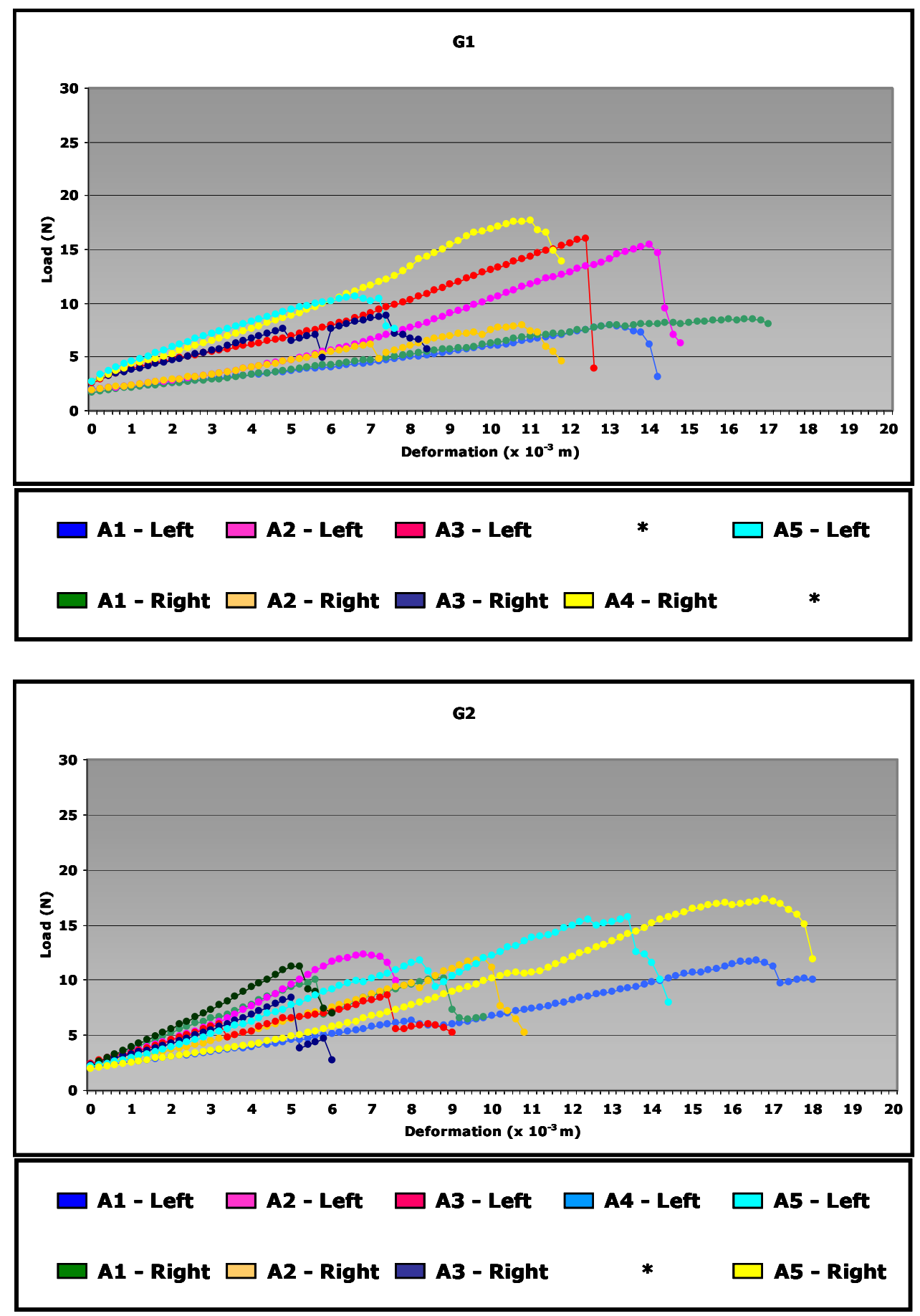

* discaded horns for they present great variation of the dispersion in the curves obtained in the graph load $x$ deformation

Figure 1 - Load $x$ deformation curves from the biomechanical study; $\mathrm{G} 1$ - controls, and $\mathrm{G} 2$ - fibrin adhesive. 


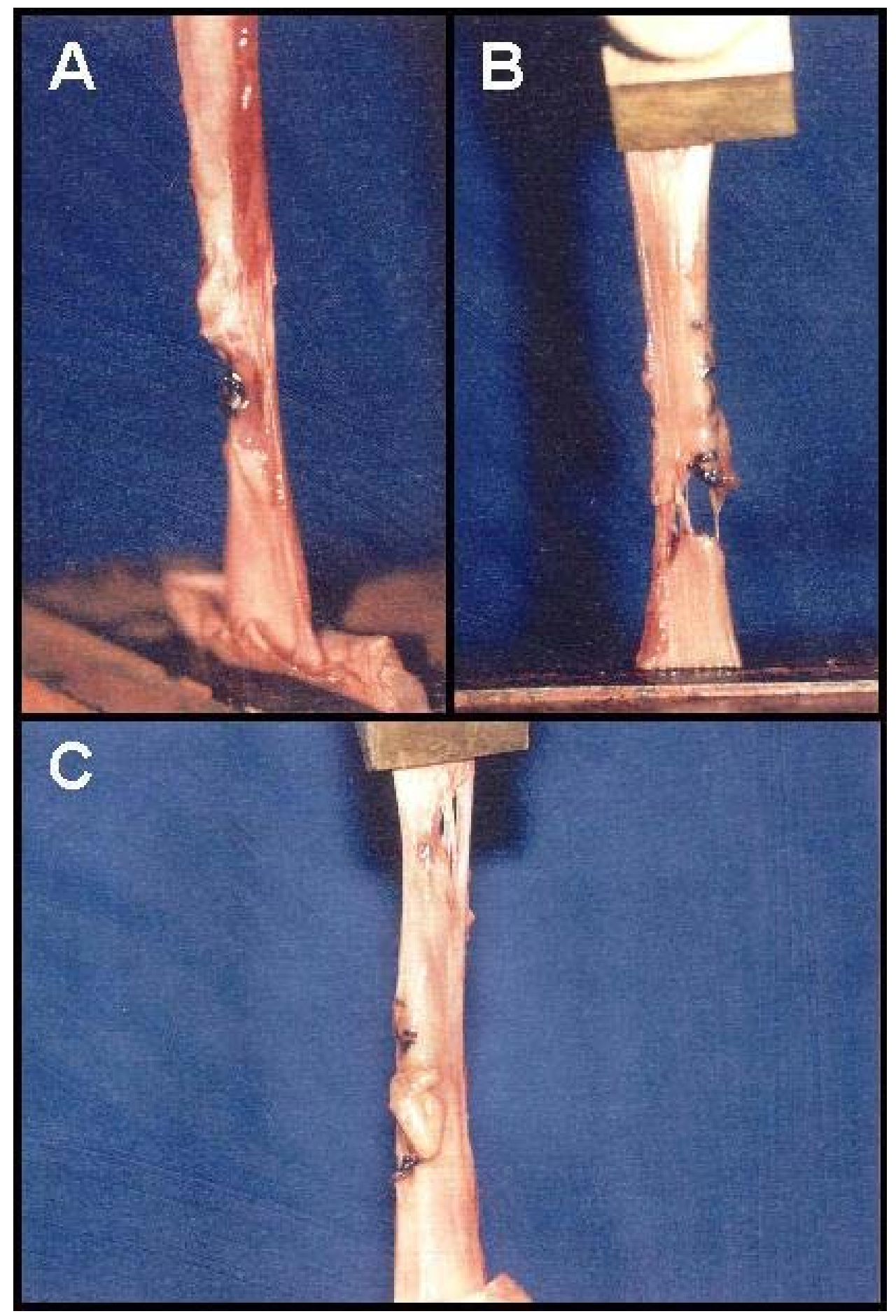

Figure 2. Different uterine horn rupture sites from the biomechanical tests: $(A)$ on the suture line; $(B)$ extremity of the suture line; and $(C)$ distal to the suture line. 
J. R. E. Moraes et al. SNAKE VENOM DERIVED FIBRIN ADHESIVE IN DOG UTERINE HEALING. BIOMECHANICAL STUDY. J. Venom. Anim. Toxins incl. Trop. Dis., 2005, 11, 2, p. 135
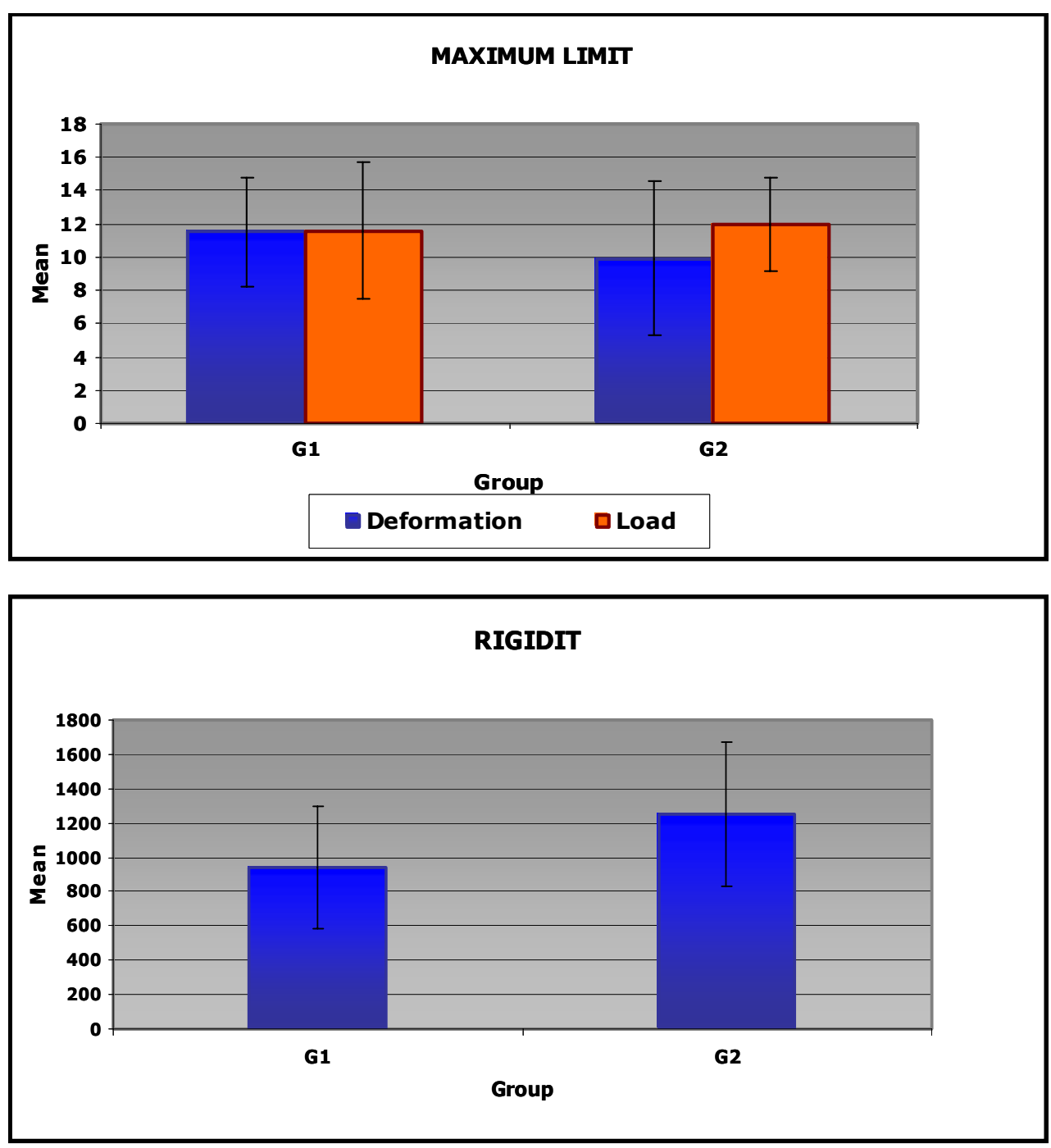

Figure 3. Means of maximum limit and rigidity values in G1 (control) and G2 (fibrin adhesive).

Table1 Ruptures sites from biomechanical tests of uterine horn fragment. 
IDENTIFICATION

ANIMAL

1

2

3

4

5

$\mathrm{L}$

$\mathrm{R}$

$\mathrm{L}$

$\mathrm{R}$

L

$\mathrm{R}$

L

$\mathrm{R}$

distal to suture

close to clamp

suture extremity

suture extremity

distal to suture

close to clamp
G2

distal to suture

distal to suture

close to clamp

on suture

distal to suture

suture extremity

suture extremity

distal to suture

suture extremity

$\mathrm{R}$

$\mathrm{L}-$ left

$\mathrm{R}$-right

G1 - Control $(n=8)$

G2 - Fibrin adhesive ( $n=9)$

* excluded horns for they present great variation of the dispersion in the curves obtained in the graph load $x$ deformation

\section{DISCUSSION}

Most surgical wounds require constant and efficient mechanical support to keep the wound edges together during healing; suture is the preferred method (25). Fibrin glue has been used in place of or as reinforcement for suture to promote hemostasis, reduce adherence, strengthen the wound site, and improve healing (6).

In addition to hemostatic properties, fibrin also promotes wound healing. It is an essential component in wound healing as it influences the formation of a lattice for fibroblast migration and hemostasis (13). The idea of using fibrin adhesive to promote faster and more efficient healing is of great interest to medical-surgical researchers. Fibrin adhesives have a hemostatic effect and good tissue adhesion, with no side effects or carcinogenic action (18).

In the 70's, fibrin glue composed of fibrinogen, factor XIII, aprotinin, fibronectin, plasminogen, thrombin, and calcium chloride was extensively studied (8). Its advantages were fast tissue repair, preventing extravasation of organ contents, and 
rapid hemostasis (7). Several beneficial effects have been reported with fibrin glue: reinforcement of esophagic anastomosis, closing of bronchopleural fistulae (1), and the treatment of hemoptisis in intrabronchial endoscopy (2). In gastrointestinal surgery, fibrin glue is mainly used in intestinal anastomoses and liver biopsy. It is also used in hepatic laparoscopy (10), and is successfully used to control bleeding in esophagic and secondary varices of portal hypertension (19).

A useful model to investigate uterine wounds was developed in rats. Incisions $(10 \mathrm{~mm})$ were made in the uterus of non-pregnant animals, and commercially available fibrin glue was used (Tissucol Duo ${ }^{\circledR}$ ). The authors concluded that fibrin associated with tissue necrosis factor $\alpha$ (TNF $\alpha$ ) has an important effect only during the initial phase of wound healing (23).

Fibrin glue derived from snake venom has been tested in different situations both in experimental animals $(9,11,15,21,22,27,28,31,32)$ and humans $(20,26)$.

Snake venom derived fibrin glue was evaluated as an alternative to conventional uterine suture after ovine caesarean surgery in pregnant ewes of known mating date. The animals submitted to conventional caesarean sections presented a better wound healing. All operated animals had retained placenta, and compromised wound edge coaptation, mainly in fibrin glue animals (6). The advantages of fibrin glue include tissue compatibility, biodegradability, and efficacy when applied to humid or highly vascularized surfaces (5); therefore further studies on its use in past caesarean hysterorrhaphy in different animal species are needed (6).

The use of snake venom derived fibrin glue in the healing process after non-pregnant canine hysterorrhaphy was evaluated. Results indicated that fibrin glue produced less inflammation in the exudative phase, and increased connective tissue deposition and angiogenesis in the proliferative and maturation phases, favoring evolution (17).

Significant advances in anesthesia and surgical sepsis have made laparohysterotomy a common veterinary obstetric procedure. Perfect uterine healing after caesarean section is pivotal for future pregnancy (30). However, despite its clinical importance, studies on the biology of wound healing in uterotomy are rare (23).

Several factors can influence uterine healing after caesarian section, such as thread type and suture pattern (25). Endocrine stimuli (12) and adequate blood supply (14) also influence uterus healing. Local factors such as perfect homeostasis, regular 
wound borders, in both the superficial and deep planes, and adequate sutures and slight tension on the wound borders are needed for a good repair (4).

There was no statistical difference between groups for: maximum load, showing that the force sustained by uterine horns in both groups was practically the same, with no influence from fibrin adhesive on the suture; maximum deformation, which indicates that the resistance of uterine horns to stretching (traction) did not change with the addition of adhesive; and rigidity, although in absolute numbers, was higher for the fibrin reinforced group - what has not been reported in literature. This could be associated with the loss of elasticity and formation of more granulation tissue in this group. The role of fibrin in promoting granulomatous healing tissue has already been confirmed by other authors. It participates in the formation of a true network, uniting wound borders, permitting and facilitating transit, adherence, migration, proliferation, and differentiation of repair cells such as fibroblasts and endothelial cells (34). These data are supported by other authors who infer the participation of fibrin in healing (15, $22,26,33,34)$.

It has also been suggested that the fibrin in the adhesives helps to form a conjunctive lattice where cells proliferate to form a scar. The action of the adhesive is probably due to the fibrin incorporation in the extracellular conjunctive matrix (31), forming a higher scar granulation tissue. Fibroplasia is favored by fibrin, as observed in a previous histological study (17).

Healing is known to offer higher resistance at the suture site; it is therefore important to evaluate the influence of fibrin on the suture. The farther the suture line is from the organ rupture, the more resistant the hysterorrhaphy; therefore rupture distal to the stitch was preferred. Rupture site results show that using fibrin adhesive as reinforcement to the suture line makes it more resistant and therefore beneficial.

\section{CONCLUSIONS}

There was no statistically significant difference between hysterorrhaphy only and hysterorrhaphy plus fibrin adhesive for the two biomechanical properties analyzed. The use of fibrin adhesive as suture reinforcement minimizes the formation of adherences on the suture line, as seen in the macroscopic evaluation of the uterus. Fibrin adhesive can be used as an adjuvant and sealant in dog uterus, providing higher rigidity and promising results. 


\section{ACKNOWLEDGEMENTS}

The authors express their thanks to the State of São Paulo Research Foundation (FAPESP) for financing this study; Center for the Study of Venoms and Venomous Animals (CEVAP), São Paulo State University (UNESP), Botucatu, São Paulo, Brazil; Laboratory of Micology, Department of Clinical Analysis, School of Pharmaceutical Sciences (FCF), São Paulo State University (UNESP), Araraquara, São Paulo, Brazil; Laboratory of Division into Fractions, Blood Bank, Ribeirão Preto School of Medicine (FMRP), São Paulo University (USP), Ribeirão Preto, São Paulo, Brazil; Laboratory of Bioenginnering, Ribeirão Preto School of Medicine (FMRP), São Paulo University (USP), Ribeirão Preto, São Paulo, Brazil.

\section{REFERENCES}

1 ANTONELLI M., CICCONETTI F., VIVINO G., GASPARETTO A. Closure of tracheoesophageal fistula by bronchoscopic application of fibrin glue and decontamination of the oral cavity. Chest, 1991, 100, 578-9.

2 BENSE L. Intrabronchial selective coagulative treatment of hemoptysis. A report of tree cases. Chest, 1990, 97, 990-6.

3 BRUHAT G., FOCCK A. Curso de física geral - mecânica II. 6.ed. São Paulo: Difusão Européia do Livro, 1964: 371-3.

4 BRUNIUS V., AHREN C. Healing of skin incisions during reduced tension of wound area. A tensiometric and histologic study in the rat. Acta. Chir. Scand., 1969, 135, 383-90.

5 BYRNE DJ., HARDY J., WOOD RA., MCINTOSH R., CUSCHIERI A. Effect of fibrin glues on the mechanical properties of healing wounds. Br. J. Surg., 1991, 78, 841-3.

6 CHALHOUB M., PRESTES NC., LOPES MD., ROCHA NS., THOMAZINI-SANTOS IA., MENDES-GIANNINI MJ. The use of snake venom derived fibrin glue in hysterorrhaphy of ovine caesarean surgery. J. Venom. Anim. Toxins, 2000, 6, 220-37.

7 COOPER CW., FALB RD. Surgical adhesives. Ann. N. Y. Acad. Sci., 1968, 146, 214-24.

8 ELLIS DAF., PELAUSA EO. Fibrin glue in fascial plastic and recontrutive surgery. J. Otholaryngol., 1988, 17, 74-7. 
9 FERRARO GC. Adesivo de fibrina derivado de veneno de serpente como promotor da cicatrização tendínea em cães. Estudo histopatológico e biomecânico. Jaboticabal: Universidade Estadual Paulista, Faculdade de Ciências Agrárias e Veterinárias, 2003. 55p. [Dissertação - Mestrado].

10 ISHITANI MB., MICGAHREN ED., SIBLEY DA., SPOTNITZ WD., RODGERS BM. Laparoscopically applied fibrin glue in experimental liver trauma. J. Pediatr. Surg., 1989, 24, 867-71.

11 IUAN FC., THOMAZINI IA., GIANNINI MJSM., TOSCANO E., VITERBO F., MORAES RA., BARRAVIERA B. Reparation of peripheral nerves with fibrin glue prepared from snake venom. Preliminary results. Rev. Paul. Med., 1995, 113, 1000-2.

12 KNOBIL E., NEIL JD., GREENWALD GS., MAEKET CL. The physiology of reproduction. 2.ed. New York: Raven Press, 1993. 2v.

13 LASA CI., KIDD RR., NUNEZ HA., DROHAN WN. Effect of fibrin glue and opsite on open wounds in DB/DB mice. J. Surg. Res., 1993, 54, 202-6.

14 LAZAROV L., STRATIEV S. The morphological characteristis of the cicatrix in repeat cesarean section. Akush. Ginekol., 1993, 32, 12-4.

15 LEITE CVS., NARESSE LE., ARANTES HL., LOPES AF., THOMAZINI-SANTOS IA., MENDES-GIANNINI MJS., MERCADANTE MC., BARRAVIERA B., KOBAYASI S. An evaluation by rat colon anastomosis of the efficacy of fibrin glue derived from snake venom. J. Venom. Anim. Toxins, 2000, 6, 180-93.

16 MORAES JRE., FERRARO GC., SHIMANO AC., BUENO DE CAMARGO MH., MORAES FR. Propriedades mecânicas de três padrões de sutura no reparo de tendão do músculo flexor profundo do dedo em eqüinos. Braz. J. Vet. Res. Anim. Sci., 2002, 39, 97-102.

17 MORAES JRE., CORREIA PHA., CAMPLESI AC., MORAES FR. Experimental use of fibrin glue derived from snake venom in non-pregnant canine uterus. J. Venom. Anim. Toxins incl. Trop. Dis., 2004, 10, 133-43.

18 MORANDINI W., ORTIZ V. Adesivos biológicos em cirurgia. Acta Cir. Bras., 1992, 7, 80-5. 
19 NAGA MI., GOUBRAN HA., SAID M., BURNOUF-RADOSEVICH M., BURNOUF T., HUART JJ. A comparison between endoscopic injection of bleeding esophageal varices using ethanolamine oleate and fibrin glue sealant in patients with bilharzial liver fibrosis. Endoscopy, 1999, 31, 405-9.

20 OLIVEIRA MDB. Aplicação de adesivo de fibrina derivado de veneno de serpente para a imobilização de enxertos gengivais livres: estudo clínico e histológico. Bauru: Universidade de São Paulo, Faculdade de Odontologia de Bauru, 2001. 63p. [Tese - Doutorado].

21 REIS FA. A comparative study of axonal sprouting from the vagus nerve in autologous grafts. J. Venom. Anim. Toxins, 2000, 6, 120.

22 SARTORI-FILHO R., PRESTES NC., THOMAZINI-SANTOS IA., MENDESGIANNINI MJS., TOSCANO E., CANAVESI AMO., BARRAVIERA B. Use of fibrin glue derived from snake venom in testicular biopsy of rams. J. Venom. Anim. Toxins, 1998, 4, 123-5.

23 SCHLENGER K., HOCKEL M., SCWAB R., BERGER RF., VAUPEL MD. How to improve the uterotomy healing. I. Effects of fibrin and tumor necrosis factoralpha in the rat uterotomy model. J. Surg. Res., 1994, 56, 235-41.

24 SHIMANO AC., SHIMANO MM. Ensaios tecnológicos de materiais biológicos. In: CONGRESSO BRASILEIRO DE ENGENHARIA BIOMÉDICA, 17, Florianópolis, 2000. Anais... Florianópolis: UDESC - CEFID, 2000:15-21.

25 SPOTNITZ WD., FALSTROM JK., RODEHEAVER GT. The role of sutures and fibrin sealant in wound healing. Surg. Clin. North Am., 1997, 77, 651-69.

26 STOLF HO. Uso do adesivo tecidual de fibrina derivado de veneno de serpente e avaliação da técnica de autoenxertia utilizando a pele do sulco nasogeniano. São Paulo: Universidade Federal de São Paulo, Escola Paulista de Medicina, 1998. 103p. [Tese - Doutorado].

27 THOMAZINI-SANTOS IA. Adesivo de fibrina derivado de veneno de serpente: efeito da adição do ácido epsilon-aminocapróico, do ácido tranexâmico e da aprotinina na coaptação das bordas cirúrgicas em incisões de pele de ratos. Botucatu: Universidade Estadual Paulista, Faculdade de Medicina, 2000. 132p. [Tese - Doutorado]. 
28 THOMAZINI-SANTOS IA., GIANNINI MJSM., TOSCANO E. The evaluation of clotting time in bovine thrombin, reptilase and thrombin-like fraction of Crotalus durissus terrificus venon using bovine, equine, ovine, bubaline and human cryoprecipitates. J. Venom. Anim. Toxins, 1998, 4, 120-36.

29 TONIOLLO GH., MORAES JRE., BRESCIANI KDS., MORAES FR. Avaliação de dois tipos de suturas uterinas em cesariana de coelhas. Ars Vet., 1999, 15, 7983.

30 VERMA SK., TYAGI RP. The effect of caesarean section and normal parturition upon the concentration of blood electrolytes, glucose and total protein in goats. Res. Vet. Sci., 1974, 16, 162-6.

31 VICENTE EJD., RODRIGUES AC., REIS FA., THOMAZINI-SANTOS IA. Suture versus fibrin adhesive: a comparative study in the peripheral nerve repair. In: WORKSHOP INTERNATIONAL DE MICROCIRURGIA DE MÃO, 5, Botucatu, 2000. Resumos... Botucatu: Sociedade Brasileira de Ortopedia e Traumatologia, 2000: 14.

32.VITERBO F., IUAN FC., THOMAZINI IA., MENDES-GIANNINI MJS., FERRARI N., PALHARES A., BARRAVIERA B., ROSA G. Reparação de nervo periférico com cola de fibrina feita com veneno de cobra e fibrinogênio de búfalo, cavalo, boi e humano. Trabalho experimental em ratos. In: CONGRESSO SOBRE CIRURGIA EXPERIMENTAL RELACIONADO À CIRURGIA PLÁSTICA, 1, Botucatu, 1994. Resumos... Botucatu: Faculdade de Medicina de BotucatuUNESP, 1994: 30.

33 WEIGEL PH., FULLER GM., LEBOEUF RD. A model for the role of hyaluronic acid and fibrin in the early events during the inflammatory response and wound healing. J. Theor. Biol., 1986, 119, 219-34.

34 ZEDERFELDT B. Does fibrin play a important role in wound healing? In: SCHLAG G., REDL H. Eds. Fibrin sealing in surgical and nonsurgical fields: wound healing. Heidelberg: Springer-Verlag Berlin, 1994: 18-22. 